\title{
ARYTENOIDCORDECTOMY FOR BILATERAL VOCAL CORD PARALYSIS: PRIMARY AND REVISION PROCEDURE
}

\author{
Zenev Ivan, ${ }^{1}$ Sapundzhiev Nikolay ${ }^{2}$ \\ ${ }^{1}$ Hospital "Queen Jioanna", Department of Oto-rhino-laryngology, \\ Medical University - Sofia, Bulgaria \\ ${ }^{2}$ Department of Oto-rhino-laryngology, Medical University — Varna, Bulgaria
}

Primljen/Received 05. 01. 2015. god.

Abstract: Background: Definitive enlargement of the glottis with preservation of adequate voicing in patients with bilateral recurrent nerve paralysis remains a surgical challenge especially in patients with previous unsuccessful surgery.

Study design: Report of a novel surgical technique for glottis enlargement and presentation of midterm results.

Methods: Four adult patients with bilateral recurrent nerve paralysis were subjected to submucosal arytenoidcordectomy through a thyreofissure approach with ventricular folds transposition and long-term translaryngeal stenting. Two of them had had previous surgeries at the glottic level. Preoperative data as well as postoperative functional results are reviewed. Follow-up ranged from 8 to 28 months.

Results: In all patients tracheostomy closure was achieved. Midterm follow-up revealed stable airway, adequate for the patients' routine physical activities. Postoperatively patients phonated with the ventricular folds and the resulting voice quality was good.

Conclusions: We describe a novel approach for management of impaired airway because of bilateral recurrent nerve paralysis and/or stenosis. It comprises intralaryngeal soft tissue resection, enlargement of the cartilaginous framework of the larynx and long-term translaryngeal stenting. The surgical approach described here proved to be successful both in patients with simple bilateral vocal fold motion impairment and in those, who have been already unsuccessfully treated with other surgery. Nevertheless the technique should be regarded as an option only in complicated revision cases, rather than a primary intervention in bilateral vocal fold paralysis.

Key words: vocal fold paralysis failure, laryngeal stenosis, arytenoidectomy, cordectomy, translaryngeal stenting.
Prihvaćen/Accepted 11. 02. 2015. god.

\section{INTRODUCTION}

Bilateral vocal fold immobility due to recurrent nerve paralysis is characterized by paramedian position of the vocal folds, narrow glottic chink and impairment of the normal respiration. Such patients are in a precarious position with respect to the airway, while the voice may be minimally impaired and they often end having some kind of surgery for enlargement of the glottis $(1,2)$. In cases when the continuity of at least one of the recurrent nerves is preserved partial restitution of the normal laryngeal function could be expected to occur within 3 to 6 months, so no radical surgery for laryngeal enlargement should be undertaken, but only temporary securing of the airway with a tracheostomy or laterofixation (3). However if the paralysis persists at the end of this period or initially both recurrent nerves were irreversibly damaged, decision should be made for further definitive treatment, as few patients are satisfied with the tracheostomy, the majority wishing to dispense with the tube (4). Numerous different surgical techniques for definitive airway enlargement, aiming the restoration of normal breathing through the nose (mouth) with maximal preservation of voice function, have been described $(5,6,7)$. None of them had shown to be definitely superior to the others, which again comes to underline the complexity of the problem (2). The major causes of surgery failure include inadequate airway with tracheostomy dependency, bad voice results or recurrent stenosis at the glottic level. The incidence of re-stenosis after first operation, though variable with the different surgical techniques and surgeons, could be as high as $40 \%$ and is much higher in already operated patients. This condition should be already considered as fibrous stenosis $(8,9)$. In attempt to solve this problem we used a modified surgical tech- 
nique for submucosal arytenoidcordectomy and enlargement of the laryngeal skeleton. This operation was implemented so far successfully in 4 patients. We report on our experience and midterm results with this new surgical intervention.

\section{MATERIAL AND METHODS}

Four patients with stenosis of the larynx at the glottic level were treated using modified submucosal arytenoidcordectomy through a thyreofissure approach with long-term translaryngeal stenting (Table 1). Of them 1 was male and the rest 3 - female, aged 37-59 years. All of them had compromised airway at the glottic level. In 3 of them the initial bilateral vocal fold motion impairment was due to recurrent nerve injury during thyroid surgery and in 1 - after gunshot wound in the upper chest and surgery. Two of the patients had had previous surgery for airway improvement in other clinics: Patient N 2 had had one cordectomy with thyreofissure approach. The postoperative course was complicated by formation of granulations. Following two endoscopic cold steel microsurgical operations with only temporary effect, and later fibrous stenosis developed. After carbon dioxide laser surgery with only temporary improvement of the airway again no decannulation was achieved. Patient N 3 had had carbon dioxide laser cordotomy 3 times at different intervals, so in between temporary decannulation and tracheotomy closure had been achieved. The patient presented to us with slowly progressing dyspnea over 5 months. Of the other two patients one presented with progressing dyspnea over 9 months 8 years after thyroid surgery and one was already with tracheostomy performed 18 months after thyroid surgery.

\section{Surgical technique}

The operation was carried out under general anesthesia. A tracheotomy was performed low in the neck in 2 patients. In the other 2 patients the existing tracheostomy was used for intubation. A vertical skin incision was made along the midline, extending from the hyoid bone to the tracheostomal opening. The platysma was incised as well. The strap muscles were separated vertically in the midline and retracted. In all patients the thyroid isthmus had been previously divided during other surgery or the whole thyroid gland had been extirpated. Further a vertical incision was made through the perichondrium of the thyroid cartilage in the exact midline with a blade. The perichondrium was dissected off the midline some $5 \mathrm{~mm}$ on either side. The cartilage was cut vertically with a rotating saw. The cut was placed just short of the inner perichondrium. After that the perichondrial and mucosal incisions were carefully completed with a blade. The thyroid laminae were lateralized with small dull retractors so good exposure of the intralaryngeal structures was achieved. Now a longitudinal incision of the mucosa from the arytenoid to the anterior commissure was made just under the vocal ligament. Inferiorly the mucosa was dissected from the underlying thyroarytenoid muscle, forming a caudally based flap. The soft tissues or local scars from the anterior commissure to the arytenoid were excised with fine long scissors. The arytenoid cartilage was separated from the periarytenoid tissues by sharp dissection, disarticulated and removed. Occasional bleeding was controlled with bipolar electrocautery. From the incision line a small superiorly based mucosal flap was created by dissecting in a submucosal plane. The caudal (subglottic) mucosal flap was carefully advanced superiorly. Both superior and inferior mucosal flaps were approximated and closed over the incision with interrupted sutures with 4-0 PDS. The anterior commissure together with the base of the epiglottis was tacked to the anterior edge of the thyroid cartilage at the level of the thyrotomy to prevent from foreshortening. The anterior ends of the ventricular folds were sutured to the external perichondrium on both sides. A PVC T-tube laryngeal stent (SD Garant-PP, Burgas, Bulgaria, Ref.: ON-0286113-92) of a corresponding size was placed in the larynx so it's superior end passed through the glottis and laid just above the ventricular folds, and the inferior end $2-3 \mathrm{~cm}$ in the trachea. The extraluminal limb was pas-

Table 1. Patient characteristics

\begin{tabular}{|c|c|l|c|c|c|c|}
\hline \multirow{2}{*}{$\mathrm{N}$} & Sex/age & \multicolumn{1}{|c|}{$\begin{array}{c}\text { Primary condition, that led } \\
\text { to paralysis or stenosis }\end{array}$} & Breathing & \multicolumn{2}{|c|}{ Previous interventions } & Operations \\
\cline { 5 - 7 } & & & Open & Endoscopic & /year \\
\hline 1. & $\mathrm{f} / 59$ & Thyroidectomy before 2 years & Tracheostomy & 0 & 0 & 0 \\
\hline 2. & $\mathrm{f} / 37$ & Subtotal thyroidectomy & Tracheostomy & 1 & 3 & 2 \\
\hline 3. & $\mathrm{~m} / 54$ & Thoracic gunshot wound and surgery & $\begin{array}{c}\text { Dyspnea since } \\
5 \text { months }\end{array}$ & 0 & 3 & 0.3 \\
\hline 4. & $\mathrm{f} / 52$ & Thyroidectomy before 8 year & $\begin{array}{c}\text { Dyspnea since } \\
9 \text { months }\end{array}$ & 0 & 0 & 0 \\
\hline
\end{tabular}




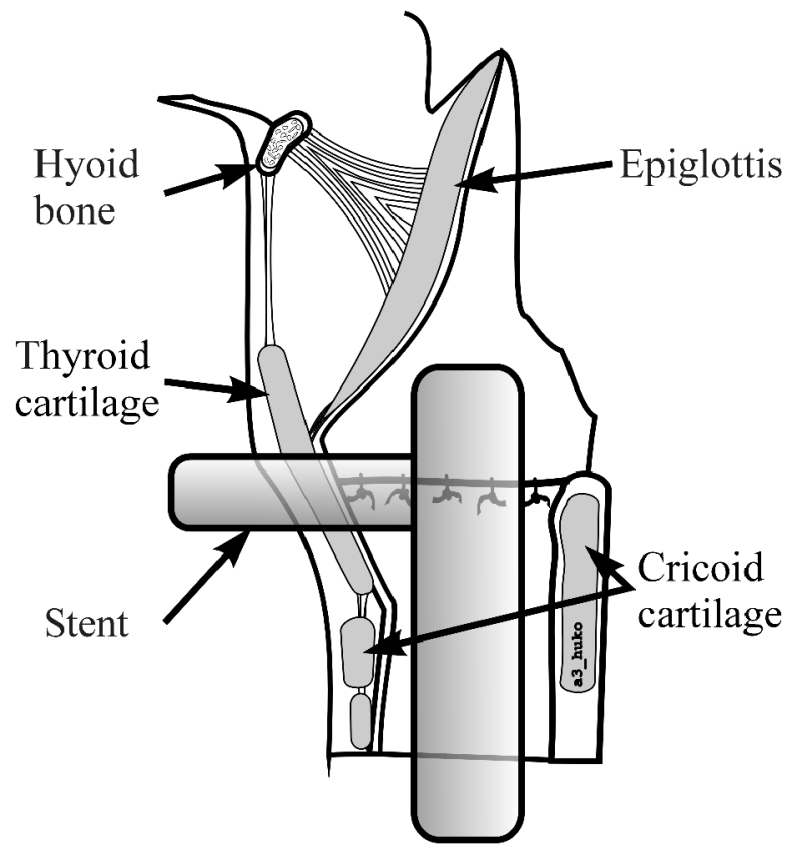

Figure 1. Translaryngeal stenting with a rigid T-Tube. The upper end lies just above the ventricular folds. The horizontal limb passes between the thyroid laminae

sed between the thyroid alae (Figure 1). An iodoform gauze pack was placed around the stent, its end was brought out through the skin incision. The midline thyrotomy was then approximated tightly with 4-0 chromic catgut suture material. The strap muscles were closed in similar fashion. A penrose drain was placed immediately overlying the thyrotomy and brought out through the inferior end of the skin incision. The platysma was closed with 4-0 chromic catgut and the skin was closed using monofilament suture material.

\section{Postoperative care}

Peri- and postoperatively patients received antibiotic for 3 to 5 days. Upon awakening after the extubation all patients resumed breathing through the stent. During the first postoperative days only occasionally cleaning of the stent through the horizontal limb with a soft suction catheter was needed. The iodoform gauze was removed over the next two days. All patients were allowed normal oral feeding on the same evening after the surgery. In one patient there was severe postoperative dysphagia with inability to swallow and aspiration with choking occurred. After indirect laryngoscopy we assumed, that this was due to high supraglottic position of the superior end of the stent, which interfered with the tilting of the epiglottis backwards and downwards in the act of swallowing. Under local anesthesia the first suture under the horizontal limb of the stent was removed and the stent was carefully pushed few milli- meters downwards. This led to significant improvement of the dysfagia so the patient was able to drink with minimal aspiration. The gradual removing of the iodoform gauze over the second and third postoperative day led to further improvement. On discharging from the hospital on the fifth day this patient could eat and drink without difficulty and aspiration (Figure 2).

The tracheostomies were left to close spontaneously by shrinking and secondary wound healing. In all but one patients total occlusion occurred within 7 days postoperatively. One month after discharging patient $\mathrm{N} 1$ presented to us at the regular follow up with minor residual opening at the place of the stoma with minimal air and secret leakage. The edges of the opening were freshened and compressive dressing was placed. Under this treatment the channel closed shortly after.

\section{Stent removal}

Between the first and the second operations the patients were followed on monthly basis. In three patients the stent was left in place for 3 months (patients $\mathrm{N} 1, \mathrm{~N} 2, \mathrm{~N} 4$ ). In patient $\mathrm{N} 3$ (with multiple operations in the neck and thorax and 3 endoscopic $\mathrm{CO}_{2}$ laser cordotomies) the stent was left in place for 6 months. Stent removal was done under local anesthesia. The old vertical scar was incised and the stent simply pulled out. The intervention lasted only few minutes. Minor bleeding was observed. No suturing of the wound was done. All patients tolerated well the second operation. They were further observed for 2 days before being discharged from the hospital. In three patients (all women) this second incision closed spontaneously within a week. In the last patient a part of the thyreofissure,

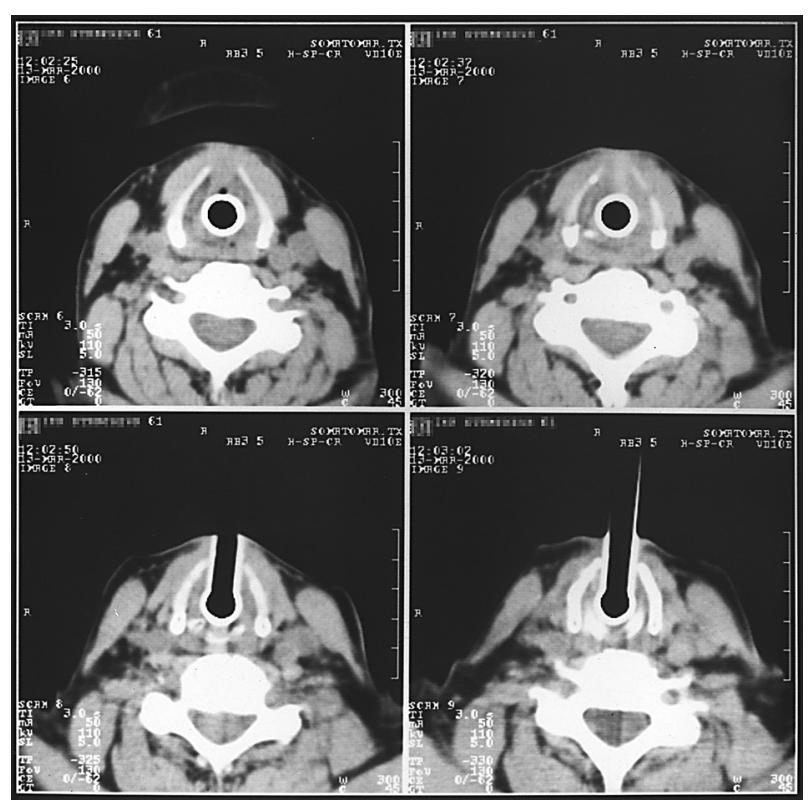

Figure 2. Patient N 1: CT-scan showing the stent in the larynx 
Table 2. Duration of stenting and midterm results

\begin{tabular}{|c|c|c|c|c|c|c|c|}
\hline \multirow{2}{*}{$\mathrm{N}$} & \multirow{2}{*}{ Sex/age } & $\begin{array}{c}\text { Duration of stenting } \\
\text { (months) }\end{array}$ & \multicolumn{2}{|c|}{ Spontaneous closure of the } & \multirow{2}{*}{ Airway } & \multirow{2}{*}{ Voice } & Follow up \\
\cline { 4 - 5 } & tracheostomy & thyreofissure & & & \\
\hline 1. & $\mathrm{f} / 59$ & 3 & No* & Yes & adequate & adequate & 28 months \\
\hline 2. & $\mathrm{f} / 37$ & 3 & Yes & Yes & adequate & good & 20 months \\
\hline 3. & $\mathrm{~m} / 54$ & 6 & Yes & No* & adequate & good & 8 months \\
\hline 4. & $\mathrm{f} / 52$ & 3 & Yes & Yes & adequate & good & 10 months \\
\hline
\end{tabular}

* These patients required minor interventions under local anesthesia for closure of the remaining airway opening.

where the horisontal limb of the stent passed, remained open. This necessitated a plastic closure - the skin laterally to the incisions was mobilized, brought to the middle line and sutured.

\section{RESULTS}

After the first operation all four patients could breathe easily through the stent. As the stent was placed quite high in the larynx with its superior end lying slightly above the ventricular folds the patients could only whisper between the two operations. Thus their communication possibilities were limited. Nevertheless two of them could have conversation over the phone. Early postoperative dysphagia developed in one patient and disappeared after adjustment of the stent position. At discharge all patients could eat and drink without aspiration to occur.

After stent removal all four patients could breathe without any difficulties. They resumed normal diet on the same day. Three of the patients reported transient mild dysphagia, but no one had signs of aspiration. In fact the risk of aspiration after arytenoidectomy is minimal and is often overemphasized.

In all four patients the resulting airway was sufficient for normal breathing so they all dispensed with the tracheostomy. $\mathrm{FEV}_{1}$ was between 80 and $110 \%$ of the predicted normal value for the sex and age. The physical activity of the patients was partially limited by concomitant diseases, but not by the airway. In patient $\mathrm{N} 2$ after stent removal small granulations were observed in the region of the former anterior commissure. With the time they showed a tendency to decrease. As after a month they still persisted, they were removed by microlaryngoscopic surgery with cold steel instruments.

After the removal of the stent two of the patients started speaking with ease. They phonated with the ventricular folds. In the other 2 patients this ability developed slowly over days to weeks. In all patients the new voice was characterized by marked roughness to a different extent, but allowed fluent conversation in their daily social and professional life. Three can have normal conversation on the phone and only one (pati- ent $\mathrm{N}$ 1) reports difficulties when having a conversation on the phone. Though in all patients reduced phonation time and limited frequency range were observed, they were satisfied with the phonatory outcome. The voice quality was satisfying as judged by the patients themselves (Table 2).

In two patients late postoperative fibrotracheoscopy revealed residual changes at the place of the old tracheostomy: in patient N 3 - stenosis (lumen reduction by $20 \%$ ); in patient $\mathrm{N} 2$ - malacic segment of the anterior tracheal wall, corresponding to 1 or 2 tracheal rings, that collapsed only in forced inspiration (lumen reduction by $10 \%$ ). Both findings were asymptomatic and did not require any surgical treatment.

\section{DISCUSSION}

Many different surgical techniques for enlargement of the glottis have been proposed and tried over almost a century, starting in 1922 with C. Jackson's "ventriculocordectomy". The majority of them are based on resection of laryngeal structures: partial or total arytenoidectomy, ventriculo-/cordectomy, arytenoidcoredctomy (2). Other interventions only retailor the structures without resecting tissue: omohyoid muscle transposition, vertical transposition of the arytenoid, cricoid split, cordotomy. A third group of surgical techniques cause minor to no tissue modifications $(2,5,6,7)$. Generally surgery for glottis enlargement has a significant failure rate of approximately $1 / 4$ of the cases and the degree of loss of the vocal capability is unpredictable (1).

Recurrences after surgery for airway enlargement in bilateral recurrent nerve paralysis develop in about $25 \%$ of the cases (8). Most often this is due to fibrosis that develops at the site of operation. All surgical techniques inevitably cause some kind of scaring. Controlled fibrosis at defined areas, which keeps the tissues in the new position and so secures the airway, is the goal of some techniques $(5,8)$. On the other hand excessive improper scaring leads to stenosis, deterioration of the functional results and makes further surgery more difficult. The newly developed scar could stretch from the anterior commissure to the arytenoid region forming 
an adventitious cord, web or a longitudinal concentric stenosis $(4,8)$. The fibrocytes have a directional memory - if incompletely excised the fibrous tissue attempts to replace itself in the original state. This phenomenon explains the difference between patients who undergo first glottis enlargement surgery and those with repetitive surgery, the second group requiring more radical surgery, stenting and nevertheless still having a doubtful prognosis (9). Another type of wound healing - the formation of granulations - could also lead to recurrent laryngeal stenosis. This type of tissue reaction is often associated with intralaryngeal stenting, $\mathrm{CO}_{2}$-laser surgery (8) or electrocautery (10). The particles of carbonized tissues that remain in the wound bed are the promoters of this process.

With the surgical technique described here, our goal was to control the process of postoperative scaring. We found the thyreofissure approach especially suitable for recurrent intralaryngeal stenosis, when endoscopic techniques fail to improve the airway. Usually the larynx is exposed through a horizontal incision (9). We initially selected the vertical skin incision in order to facilitate the implantation of the stent and its removal in the second stage.

The majority of surgical interventions for airway enlargement aim at the posterior "respiratory" part of the glottis, leaving the anterior ligamental two thirds of the vocal cords — the "phonatory" part — as intact as possible (7). Nevertheless enlargement of the anterior glottis has already been reported with good phonatory results $(11,12)$. Thyroid cartilage enlargement (expansi-

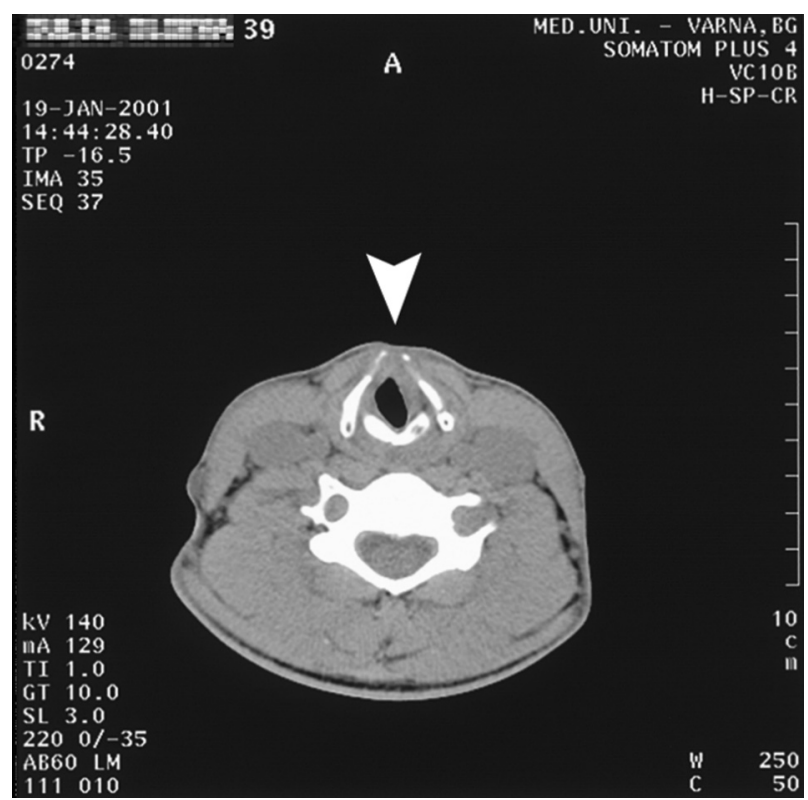

Figure 3. Patient N 2: CT-scan 4 months after the stent removal. The glottic level is widely opened and stable. The plates of the thyroid cartilage lay separated by a plaque of fibrous tissue (arrow) on laryngoplasty, or type II lateralization thyroplasty) was described as voice improving operation in spasmodyc dysphonia, but not as an airway enlarging one (13). In the technique described here we used a similar approach for enlargement of the whole glottic plane - arytenoid cartilage and vocal fold are removed and the thyroid plates are separated and retracted laterally till the scar tissue in between gets stable, so they could remain in this position after the removal of the stent. In our patients the gap between the two anterior thyroid edges remained clearly palpable under the skin.

The submucousal approach for the soft tissue resection, followed by meticulous closure of the mucosal flaps over the wound allows minimizing the risk of formation of granulations. The intraluminal stenting is often used for protecting the lumen in the early postoperative period. In the majority of surgical techniques described in the literature, only short-term intraluminal stenting is used - from 24 hours (7) to about 2 weeks (5). We deliberately chose to stent our patients in a translaryngeal way over a long period of time till we obtain a solid, mature fibrous plaque between the both thyroid allae, which would be able to keep them retracted (respectively the lumen of the airway broad) after the removal of the stent (Figure 3). Three months proved to be a reasonable period of time (14). Longer periods of stenting could be recommended in patients, who had had unsuccessful surgery and severe stenosis. We have observed our patients for 8 to 28 months after the removal of the stent. In no one the airway showed tendency to restenose to a clinically manifest degree.

Special cannulas with third upper part projecting into the larynx were used already at the end of the first quarter of 20-th century. The main respiratory flow passed through the stoma like in a usual cannula and they were to be changed daily (15). In the sixties Montgomery introduced the silicon (dimethylpolysiloxan) T-stents (16). The outer limb of the stent is to be plugged all the time. The patient breathes along the normal airway and so coughs more effectively, which is the major mechanism for natural cleaning of the stent. Such a stent does not require daily change. Being flexible the Montgomery silicon T-stents are well adapted for stenting the trachea. We used a T-stent made of PVC. It is more rigid than the silicon one, while being still elastic. To completely compress it a force 6 times greater is needed than for the original silastic Montgomery stent (Fig. 4). In this way the stent used by us allowed adequate retraction of the thyroid alae, where a normal silastic Montgomery T-stent would collapse. Here again the horizontal limb should be occluded, to allow respiration along the normal airway. If this simple rule is obeyed the stent could be safely left in place for months. 


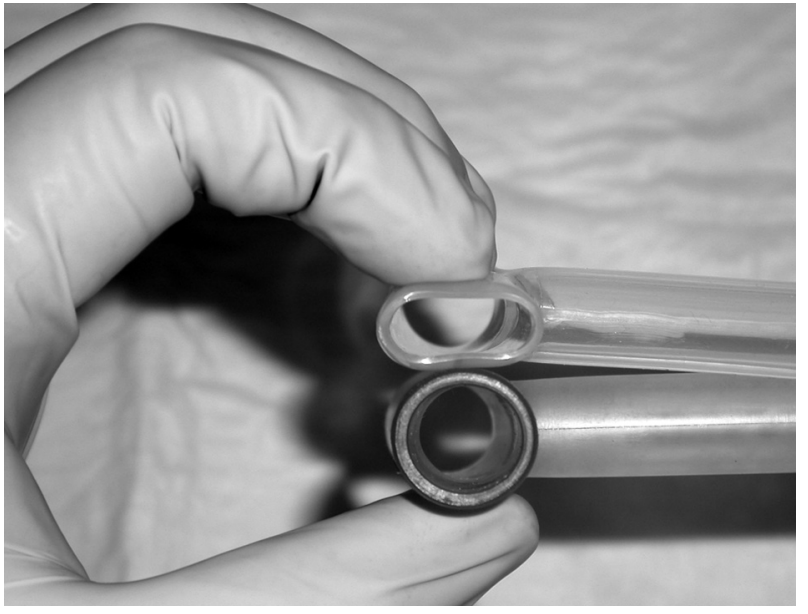

Figure 4. The T-tube used by us (below) is more rigid than the silicon one (above), is hardly to be compressed, but is still flexible

In bilateral recurrent nerve paralysis (paramedian position of the vocal folds) the phonatory function of the larynx is relatively little influenced in comparison with the respiratory. The weak collateral innervation of the intralaryngeal musculature by minor fibers of the n. laryngeus superior allows a general and badly coordinated spasm so the glottis takes a voicing position close to normal. When reviewing articles, describing surgery for glottic enlargement we found little to no information on the mechanism of postoperative voicing and the structures that actually produce the sound. Most of the authors comment only on the quality of the voice. In our group of patients we clearly could identify, that after the removal of the stent the patients started to phonate with the ventricular folds (dysphonia plicae ventricularis). This ability developed gradually for several days to weeks and was supported by speech therapy. Leading role for the movement of this neoglottis play the stylopharyngeus and palatopharyngeus muscles, innervated by the pharyngeal plexus. When contracting they push the arytenoid towards the midline and so approximate the ventricular folds $(15,17$, 18). In the surgical technique we use, we consider the suturing of the anterior parts of the ventricular folds to the external perichondrium of the thyroid alae an important point of the operation. In this way they are stretched and brought closely together at the anterior part of the larynx, so even after the total enlargement of the cartilaginous framework, they remain quite close to each other and so form a new phonatory substrate.

The complications we observed in these four patients were related to the stent. In one patient severe dysphagia and aspiration occurred immediately after the operation. After correction of the stent position and removal of the iodoform gauze these symptoms disappeared. In another patient after stent removal we observed minimal granulations at the anterior commissure. Though they remained clinically irrelevant and even slow regression was observed, we decided to remove them by endoscopic microsurgery.

\section{CONCLUSION}

The surgical technique we use for restoration of the airway in patients stenosis at the glottic level comprises thyreofissure, submucosal arytenoidcordectomy and stretching of the ventricular folds. Long term translaryngeal stenting provides enlargement of the whole cartilaginous framework of the larynx. The resulting airway was stable in all patients with maximal follow up of 28 months. The intervention allowed all patients to dispense with the tracheostomy tube. Postoperatively patients phonated with the ventricular folds. Voice quality was good and allowed conversation with ease. Aspiration was limited to a minimum. The surgical technique described is not to be recommended as a primary treatment for bilateral vocal fold paralysis, because of the massive trauma to the larynx and the poor phonatory outcome. It should rather be regarded as an option for cases with failure of primary and/or revision surgery for glottic enlargement, where laryngeal stenois had developed and the patients remain tracheostomy-dependent. In our hands this technique proved to be effective in patients with previous unsuccessful surgery for bilateral vocal fold paralysis and partial fibrous stenosis.

\title{
Sažetak
}

\section{ARITENOIDKORDEKTOMIJA KOD BILATERALNE PARALIZE GLASNIH ŽICA: PRIMARNA I REVIZIONA PROCEDURA}

\author{
Zenev Ivan, ${ }^{1}$ Sapundzhiev Nikolay ${ }^{2}$
}

${ }^{1}$ Bolnica "Carica Ioanna”, Odeljenje za otorinolaringologiju, Medicinski fakultet Univerziteta u Sofiji, Bugarska ${ }^{2}$ Odeljenje za Otorinolaringologiju, Medicinski fakultet Univerziteta u Varni, Bugarska

Uvod: Definitivno proširenje glotisa uz očuvanje govora, kod pacijenata s bilateralnom paralizom reku- rentnog živca, ostaje hirurški izazov, posebno kod pacijenata sa prethodno neuspelom operacijom. 
Cilj: Prikaz nove hirurške tehnike kod proširenja glotisa i prikaz rezultata.

Metod: Četiri odrasla pacijenta sa bilateralnom paralizom rekurentnog živca podvrgnuti su submukoznoj aritenoidkordektomiji, kroz tireofisuru, sa transpozicijom ventrikularnih nabora i dugoročnim translaringealnim stentom. Dva pacijenta, od njih četvoro, su imala prethodne operacije na nivou glotisa. Preoperativna medicinska dokumentacija, kao i postoperativni funkcionalni rezultati su pregledani. Praćenje je trajalo od 8 do 28 meseci.

Rezultati: Kod svih pacijenata je postignuto zatvaranje traheostome. Tokom praćenja uspostavljen je stabilan vazdušni put, adekvatan za rutinske fizičke aktivnosti pacijenata. Postoperativno, pacijenti su fonirali sa vestibularnim naborima i rezultirajući kvalitet glasa je bio dobar.

\section{REFERENCES}

1. Tucker HM. Rehabilitation of the immobile vocal fold. In: Fried MP, editor. The larynx. A multidisciplinary approach. 2nd ed. St. Louis: Mosby; 1996. p. 215-7.

2. Sapundzhiev N, Lichtenberger G, Eckel HE, et al. Surgery of adult bilateral vocal fold paralysis in adduction: history and trends. Eur Arch Oto Rhino Laryngol. 2008; 265(12): 1501-14.

3. Werner JA, Lippert BM. Laterofixation der Stimmlippe stat Tracheotomie bei akuter beidseitiger Stimmlippenparese. Dtsch Med Wochenschr. 2002; 127(17): 917-22.

4. Downey WL, Kennon WG Jr. Laryngofissure approach for bilateral abductor paralysis. Arch Otolaryngol. 1968; 88(5): 513-7.

5. De Campora E, Camaioni A, Corradini C, D'Agnone N, Calabrese V, Croce A. Thornell's approach for arytenoidectomy in the surgical treatment of bilateral abductor paralysis; personal experience and results. J Laryngol Otol. 1985; 99: 379-82.

6. Danino J, Goldenberg D, Joachims HZ. Submucosal arytenoidectomy: new surgical technique and review of the literature. J Otolaryngol. 2000; 29(1): 13-6.

7. Remacle M, Lawson G, Mayné A, Jamart J. Subtotal carbon dioxide laser arytenoidectomy by endoscopic approach for treatment of bilateral cord immobility in adduction. Ann Otol Rhinol Laryngol. 1996; 105(6): 438-45.

8. Ossoff RH, Sisson GA, Duncavage JA, Moselle HI, Andrews PE, McMillan WG. Endoscopic laser arytenoidectomy for the treatment of bilateral vocal cord paralysis. The Laryngoscope. 1984; 94(10): 1293-7.

9. Sessions DG, Ogura JH, Heeneman H. Surgical management of bilateral vocal cord paralysis. The Laryngoscope. 1976; 86(4): 559-66.

\section{Correspondence to/Autor za korespondenciju}

Nikolay Sapundzhiev

Department of Oto-rhino-laryngology

Medical University - Varna, Bulgaria

Marin Drinov str. 55, Varna 9002, Bulgaria

Telephone: 00359 (0) 52978571

E-mail: n.sapundzhiev@gmail.com
Zaključak: Opisali smo nov pristup za tretman oštećenih disajnih puteva zbog bilateralne paralize rekurentnog živca i / ili stenoze. On obuhvata resekciju intralaringealnog mekog tkiva, proširenje hrskavičavog zida grkljana i dugoročni translaringealni stent. Opisani hirurški pristup pokazao se uspešnim kod pacijenata sa jednostavnim, bilateralnim oslabljenim pokretima glasnih žica i kod onih koji su već neuspešno lečeni drugom hirurškom tehnikom. Ipak, ovu tehniku treba razmatrati kao opciju samo u komplikovanim revizionim slučajevima, a ne kao primarnnu intervenciju kod bilateralne paralizom glasnih žica.

Ključne reči: paraliza glasnih žica, stenoza grkljana, aritenoidektomija, kordektomija, translaringealni stent.

10. Gray S, Miller R, Myer CM, Cotton RT. Adjunctive measures for successful laryngotracheal reconstruction. Ann Otol Rhinol Laryngol. 1987; 96(5): 509-13.

11. Eckel HE, Thumfart M, Wassermann K, Vössing M, Thumfart WF. Cordectomy versus arytenoidectomy in the management of bilateral vocal cord paralysis. Ann Otol Rhinol Laryngol. 1994; 103(11): 852-7.

12. Kleinsasser O. Endolaryngeale Arytenoidektomie und submuköse Hemichordektomie zur Erweiterung der Glottis bei bilateraler Abduktorenparese. Mschr Ohr Laryngorhinol. 1968; 102: 443-6.

13. Friedrich G, de Jong FI, Mahieu HF, Benninger MS, Isshiki N. Laryngeal framework surgery: a proposal for classification and nomenclature by the Phonosurgery Committee of the European Laryngological Society. Eur Arch Oto Rhino Laryngol. 2001; 258(8): 389-96.

14. Zenev I, Sapundzhiev N. Dilating stents used in laryngotracheal stenosis with a report of one case. Annual proceedings IMAB. 2000; 6: 296-7.

15. Rethi A. Eine neue operative Behandlung der beidseitigen Paramedianstimmbandfixation mit einem Hinweis auf die Operation der narbiger Kehlkopfstenose. Z Für Laryngol Rhinol Otol Ihre Grenzgeb. 1955; 34(7): 464-72.

16. Montgomery WW. Silicone tracheal T-tube. Ann Otol Rhinol Laryngol. 1974; 83(1): 71-5.

17. Langnickel R. An endolaryngeal method of vertico-lateral transposition of the vocal cord for bilateral abductor paralysis. The Laryngoscope. 1976; 86(7): 1020-8.

18. Thomé R, Thomé DC, Behlau M. The use of buccal mucosa graft at posterior cricoid splitting for subglottic stenosis repair. The Laryngoscope. 2001; 111(12): 2191-4. 